\title{
Christian Morals and the Ideal of Chastity as reflected in Medieval Hungarian Sources
}

This paper discusses the origin of the idea of chastity and sexual rigorousness in relation to the society of the Slovak territory in the early Middle Ages. The oldest sources are the so-called Moravian-Pannonian Legends, namely the Life of Constantine and the Life of Method. The above-mentioned outlook of the author is to be found in Moravian legal texts where sexual crimes and their punishments are of great importance. While the idea of chastity and sexual rigorousness had an important place in legal texts of the 9th century, this topic is represented rather briefly in the legends. The opposite can be observed in the period of the dynasty of Arpád in the Hungarian Kingdom, where we encounter two legends originally based on the above-mentioned ideas. To us, these legends are known as the Legend of Saint Emeric and the Legend of Saint Margaret. Emeric was described as a monarch's son who decided to remain a virgin for his entire life. He took this decision despite his status as the heir to the throne and a married man. Margaret spent her short life in a monastery and the legend does not only describe her repugnance to marriage, but also her unattractive looks and disregard towards personal hygiene.

Keywords: Arpádians - chastity - legends - Moravia - sexual rigorousness

In this paper, we will attempt to examine the influences of canon law and Christian norms on the normative systems of archaic communities, and the relationship between them. We will see how these systems came into the conflict, perhaps in the same way, as an ideal (normative imperative) and a reality. As the object of interest is a barely Christianized society in Hungary, we can confront this material with that from the $9^{\text {th }}$ century, when Christianization on the territory of Moravia came through and the territory of Central Europe was under the influence of the Cyrillo-Methodian mission. We will try to find out the extent to which it is possible to find similarities between the two countries.

The majority of the written (especially narrative) sources from the early and high Middle Ages were created by clerics, who no doubt derived their stances and value judgements from their status, education and position in the church hierarchy. Therefore, their value judgements could generally differ from the attitudes of laymen. Even though this postulate is hard to prove directly (the authors are usually unknown and lay authors are rare in our environment), in our view, it is seen as very probable.

The relationship between the ideals framed by Christianity and criminal law in the past is not easy to describe. Still, it is useful to mention that the societies of the early or high Middle Ages did not know the term criminal law. What existed was simply the law, and members of society distinguished between the right and the wrong, and the right could be violated. Law was rather a procedural tool for remedy. Therefore, it was easier to terminologically grasp Christian Law, ${ }^{1}$

\footnotetext{
${ }^{1}$ The Moravians (or members of the CyrilloMethodian mission, but perhaps general the Slavs) expressed their Christian faith with the term ЗАКОНЪ (law). See: Žitije Konstantina, c. 14, in: BARTOŇKOVÁ, Magnae Moraviae fontes historici II, 99.
} 
distinct from archaic law not only by the content of the rules, but also by its strictness and the ways of their enforcing. ${ }^{2}$

The relationship of domestic customary (archaic) law and canon law was a relationship of competing, mutually antagonistic rules that could differ not only in respect to disposition, but also regarding the sanctions. These two systems coexisted side by side, influencing one another while modifying and getting accustomed to the oncoming social changes. To understand the conflicting systems that were contrary to one another, we can retell the conflict between the Prague archbishop Adalbert and the Czechs that ended with the murder of his family and his own retreat from Bohemia. What Adalbert disliked in the first place were the noncanonical marriages among the Czechs; however, he also was keen on collecting decimae and erecting churches.

The most serious controversy, however, was the conflict between Adalbert and a Czech clan due to a noble woman who had committed adultery with a cleric. Adalbert decided to hide this woman in a monastery in order to save her life while being aware of the possibility of being killed by the mob and thus to obtain martyrdom for himself. However, the family of the deceived husband told Adalbert that the revenge should not fall upon Adalbert himself but on his brothers, their wives and children, as well as on their property. Meanwhile, the adulteress was found kneeling at the altar, and beheaded. ${ }^{3}$ This story actually expresses the conflict between the archaic law of the Czech Slavs and canon law. The former comprised a merciless application of

\footnotetext{
${ }^{2}$ For more details see GLUCHMAN, Krestanstvo a morálka.

${ }^{3}$ Vita antiquior auctore Iohanne Canapario, c. 19, in: PERTZ, Monumenta Germaniae historica 589f. Here, in this part of the legend, Saint Emmeram of Regensburg cultus is possibly reflected, as he defended the daughter of the Bavarian duke because of her fornication. See Tř̌šTíK, Počátky Přemyslovců 252.
}

sanctions (reformation), the latter was directed not only to a less severe judging of women, but obviously contained also the institute of the right to asylum. Not only particular individuals were affected in the former, but claiming remedy (in the form of killing the adulteress) was the matter of the entire clan, who collectively bore obligations and claimed rights. Similarly, the "damage" was claimed collectively from Adalberts's family, who were to be held liable for Adalbert's decision to shield the woman and thus to prevent her beheading. The blood feud towards Adalbert's family members was completed at the Slavnik castle at Libice, leading in turn to the departure of Adalbert from Bohemia. ${ }^{4}$

This case from the late $10^{\text {th }}$ century resembles in some features the fate of the Hungarian Queen Gertrude, the wife of Andrew II (1205-1235). The Hungarian Chronicon Pictum asserts that she had forced the wife of Banus Bank to commit adultery. Bank decided to take revenge against the Queen directly and he succeeded by killing her with a sword. The chronicler then only vaguely mentions the bloodshed in the Bank clan (he came from the Bor family). ${ }^{5}$

The severity of these archaic rules was simply based on the notion described by Hans Hattenhauer as the non-existence of mercy - if such a law was breached (and so was the divine order),

\footnotetext{
${ }^{4}$ Convincing analysis of this event made by TŘEŠTíK, Zápisník a jiné texty 195-204. TŘEŠTík, Co se stalo 28. září 995 ?.

${ }^{5}$ Chronici Hungarici compositio saec. XIV., c. 174, in: SZENTPÉTERY, Scriptores rerum Hungaricarum I, 464f: "Sed proh dolor, humani generis inimico procul dubio stuadente uxorem Banc bani magnifici viri, domina memorata (Gertruda) vi tradidit cuidam suo fratri hospiti deludendam. Quam ob causam idem Bank banus de genere Bororiundus suum gladium in regine sanguine miserabiliter cruentavitet diro vulnere sauciatam anno Domini M-o CC. XII. interfecit. [...] Pro cuius nece vox flebilis insonuit in tota Pannonia et in omni genere Bank bani execrabilis et horrendas sanguinis effusio subsecuta."
} 
man could not give up settlement in such a case. This actually meant that the goal of archaic law was not an effort to reform the sinner from whom no repentance was expected. The goal was to cure the wrong by redemption, which had nothing in common with a compensation for the damage caused, as compared to modern law. ${ }^{6}$ Canon law brought a new merit in the sense that the sinner (later denoted as perpetrator) was brought to the centre of the dispute and his wrongdoing was to be judged from the view of ethics.

It is useful to supplement the sources of legal history (e.g. formal sources on the rise of law or the sources on the knowledge obtained through legal experience and activities) also with nonlegal sources of learning law, especially those concerning the periods where legal texts are a supplementary source of law only, or they do not exist at all. It was the Slovak legal historian Štefan Luby who in his time denoted legends and chronicles as the most significant non-legal sources of learning law.

Although legends no doubt belong to the area of non-legal texts, this should not cause us to misunderstand their nature. Of course, their main role is to present the figure of the saint, his life and death; however, this text is also normative, as the saint's life is depicted as worthy of being followed, or at least honourable. It is not the saint himself who is worthy of being followed in the first place, but rather the values represented by him. This statement applies especially when we presume that a considerable discrepancy between the real life and the picture of the saint could have existed, which was caused by the effort of the author of the text of the legend to have the exemplary life of the saint stand out.

Regarding the relationship to marital and spousal life it is good to bring to notice the parts from the hagiographic texts of Great Moravia

${ }^{6}$ HATtenHAUeR, Evropské dějiny práva 16. where the decision of Constantine-Cyril not to live in marriage is mentioned. Firstly, Constantine reportedly had a dream where he was supposed to choose among the girls of Thessaloniki, and he symbolically selected wisdom (i.e. he chose none of them); this eventually led his parents to send him to study. ${ }^{7}$ A similar concept can be found in the next chapter of the Life of Constantine, where the logothete of Constantinople encouraged him to marry his goddaughter as well as to obtain a considerable profane rank; but when Constantine declined, he recommended to him the profession of librarian. ${ }^{8}$

Regarding moral wrongs, the Life of Method contains a part on marriage entered into by relatives that breached canon law principles (it is not quite clear from the text whether these were marriages of spiritual or blood-related relatives). ${ }^{9}$ It is interesting in this text that the spouses were not punished by a secular power, which only supports the presumptions on difficulties in applying Christian rules in practice; however, the couple was punished by "perdition" and reportedly nobody was able to find their dead bodies. ${ }^{10}$

The relationship between the prude Moravian archbishop Method and Svätopluk was sometimes discussed;11 some sources depict Svätopluk not very nicely. According to the Life of Clement, Svätopluk was a voluptuary dependent on women, wallowing in the mud of

\footnotetext{
7 Žitije Konstantina c. 3, in: BARTOŇKOvÁ, Magnae Moraviae fontes historici II, $62 \mathrm{f}$.

${ }^{8}$ Ibidem, c. $466 \mathrm{f}$.

9 Žitije Mefodija, c. 11, in: BARTOŇKOVÁ, Magnae Moraviae fontes historici II, 157.

${ }^{10}$ Ibidem, c. 11, 158. Let us mention that the purpose of the eleventh chapter of the Life of Method was to prove the prophetic nature of the Moravian archbishop.

${ }^{11}$ E.g. TŘEŠTík, Počátky Přemyslovců 283; KUČERA Král' Svätopluk 102.
} 
loathsome lecheries ${ }^{12}$ so much as to lose his common sense. ${ }^{13}$ Of course, the Life of Clement was written from a considerable distance as for time and place, based on the works of emigrants from Moravia who obviously shared the view of a sinful character of the Moravian Prince Svätopluk. Therefore, it does not make sense to dispute the authenticity and reliability of this source; it will be sufficient to emphasize that the author's goal was the denunciation of the Latin party in Moravia led by the sovereign himself, and he did so by using the dirty sexual urges of the Prince. In comparison, the Moravian legal texts of the $9^{\text {th }}$ century strongly emphasized rigorousness toward sex. This can be seen also in the text of Anonymous Homily where the author (probably the archbishop Method) stresses, using the words of the Apostle Paul, that "fornication, and all uncleanness, or covetousness, let it not be once named among you, as becometh saints" (Eph 5: 3). ${ }^{14}$ The same appeal was contained in Jesus' quotation from the Gospel of Matthew, saying that "whosoever shall put away his wife, except it be for fornication, and shall marry another, committeth adultery" (Mt 19: 9), because "[w] hat therefore God hath joined together, let not man put asunder" (Mt 19: 6). ${ }^{15}$

Eventually, sexual delicts were mentioned in the translation of the Nomocanon into Old Church Slavonic, where several articles dealt with sexual offenses. For example, the Nomocanon's Article 40 contains ecclesiastical sanctions for women who killed children born from adultery, or induced abortion, for which they should be peni-

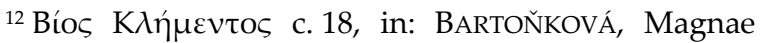
Moraviae fontes historici II, 213.

${ }^{13}$ Ibidem, c. 31, 225.

${ }^{14}$ Vladykamъ zemlę, in: HAVLÍK, Magnae Moraviae fontes historici IV, 201f.

${ }^{15}$ Ibidem. This Bible verse is quoted in the Nomocanon, too. See Nomokanon 41, in: HAVLíK, Magnae Moraviae fontes historici IV, 338.
}

tent for ten years. ${ }^{16}$ Adultery of women or men should be punished less strictly, by seven years (of penitence). ${ }^{17}$ The Nomocanon's article 41 prohibited adultery of a cleric's wife (ПРЕАЮБЫ СТВОРИТЬ in the original ${ }^{18}$ ); the husband involved could either not be ordained canonically, or - in case he was already ordained - had to repudiate his wife. ${ }^{19}$ It was very strictly forbidden in the Nomocanon to repudiate a wife and take a new one; wives were forbidden to marry again without producing a reliable attestation about the death of the former husband. ${ }^{20}$ Article 42 contains a ban for fiancées that had been kidnapped and raped; they should be returned to their fiancés. As for the commencement of marriage, there is an interesting ban on concluding a marriage without consent of the parents or lords, otherwise such a marriage would be considered fornication. ${ }^{21}$ If we pass on to other articles of the Nomocanon, we can read ecclesiastical regulations on such circumstances as when a person entered into marriage several times. In principle, the opinion on the third connubium was negative, whereby more connubia were considered skulduggery (СКOTЬCKO), worse than fornication. The ban concerned also the bathing together of men and women. In contrast, article 43 was more benevolent towards the intention to commit fornication if this sin did not materialise, because obviously the person was absolved of this thanks to divine grace. ${ }^{22}$ More serious wrongs against Christian morals were resolved further in article 44, like "marriage with two brothers" or "marriage with two sisters" (even at different times), incest (includ-

\footnotetext{
${ }^{16}$ Ibidem 337.

17 Ibidem 337.

${ }^{18}$ For the linguistic character of the Nomokanon's articles see JÁGER, Nomokánon 253f.

${ }^{19}$ Nomokanon 41 in: HAVLÍK, Magnae Moraviae fontes historici IV, 338.

${ }^{20}$ Ibidem 339f.

${ }^{21}$ Ibidem 340-342.

22 Ibidem 342-344.
} 
ing with a step-mother), a (second) marriage between father-in-law and daughter-in-law, or sodomy (sexual intercourse with animals). ${ }^{23}$

A rich catalogue of sins in the Nomocanon, relating to sexual delicts of both laymen and clerics, together with other sources indicates considerable attention given to sexual strictness in the $9^{\text {th }}$ century under the impact of the CyrilloMethodian mission. The legal text can be seen as developing the rules contained in hagiographic texts (of course, the Life of Method originated only later ${ }^{24}$ ), and thus hagiographic texts had become the key normative text bringing to understanding the sense of Christian rules in the society of neophytes, as Moravia was in the $9^{\text {th }}$ century after its Christianisation. ${ }^{25}$ The tension between normativity and reality was great. This is reflected in the considerable number of sexual wrongs in legal texts, as well as in the condemnation of Prince Svätopluk in the Life of Clement, which, although originating in a Bulgarian cultural environment, in its normative nature quite satisfactorily responded to Central Euro-

\footnotetext{
${ }^{23}$ Ibidem 342-347.

${ }^{24}$ The origin of the Nomocanon was studied by several authors, who usually based on a linguistic analysis assume that this text was created as late as after 873 , when Method came from imprisonment in Bavaria. This conclusion is based on the Moravian character of the Nomokanon's terminology that could be only used after long-term commorancy in Moravia. VAŠICA, Literární památky 63; STANISLAV. Starosloviensky jazyk I, 208f.; KIZLINK, Právo Vel'kej Moravy 462.

25 The origins of Christianity in Moravia were a muchdiscussed question; the semi-official year is 831 and it is preserved in the tradition of Passau. Historia episcoporum Pataviensium et ducum Bavariae ad a. 838, in: WAITZ, Monumenta Germaniae historica, 620: "Reinharius archiepiscopus Laureacensis et Pataviensis apostolus Maravorum obit." Notae de episcopis Pataviensis, in: ibidem 623: "Regenharius episcopus Matavorum baptizat omnes Moravos." Bernardi Cremifanensis historiae ad aa. 818-838 in: ibidem 655: "Item Renharius episcopus baptizat omnes Moravos." For an analysis of these sources, see DITTRICH, Christianity in Great-Moravia 61-65.
}

pean conditions and may have been linked with the negative tradition on Svätopluk. It is the labelling of Svätopluk as a slave of sexual drives towards women that proves the entrenchment of the rules on sexual strictness among clerics.

The continuity of Christianity in the territory of contemporary Slovakia between the $9^{\text {th }}$ century and the Hungarian kingdom has been described many times. As for church administration, the possibility of maintaining the tradition of the Nitra diocese can be considered, ${ }^{26}$ however, the continuity of maintaining the Christian belief can be safely taken for granted; it can also be proven by the original Slavonic terminology found in the Hungarian language. Contacts between originally Old Church Slavonic terminology and the Hungarian language could have occurred not only in the territory of contemporary Slovakia, but also in Pannonia, populated by Slavs to a great extent, which was also influenced by the mission of Constantine and Method.

New stimuli of Christianity came to Hungary from abroad in many respects. The fact was that many strangers came to the royal court of King Stephen and his successors (their reflections in Hungarian sources will be discussed later) and these strangers were often the authors of our literary and legal sources, which will be analysed further on. Although a combination of both Western (Latin) and Eastern (Byzantine) impacts can be observed in Moravia, the Byzantine influence in its written sources apparently prevailed. In contrast, Byzantine influences in Hungary can be deemed marginal. Still, many

\footnotetext{
${ }^{26}$ The first bishop of the Nitrian church was Wiching, mentioned in the papal letter Industrię tue of $880 \mathrm{AD}$. BARTOŇKOV, Magnae Moraviae fontes historici III, 205. "Ipsum quoque presbiterum nomine Uuichinus, quem nobis direxisti, electum episcopum consecravimus sanctę ecclesię Nitrensis." For the question of church administration continuity, see MARSINA, Obnovenie Nitrianskeho biskupstva 35-45.
} 
similarities can be seen in respect to sexual strictness.

The most interesting material is presented by legends depicting the Arpád dynasty. It should be noted that a considerable number of saints (compared to other European dynasties) came from this large family (Saint King Stephan, Saint Prince Emeric, Saint Ladislaus, Saint Elisabeth of Thuringia, Saint Margaret). When leaving out St. Elisabeth, ${ }^{27}$ legendary in the German-speaking world, and ignoring St. Stephan legends, as they are not subject of this paper, quite an interesting matter remains in the form of two legends that are also related to one another by topic.

The first example is the Legend of St. Emeric, son of Stephan I (997-1038), describing his life. The legend was written prior to Emetic's beatification in 1083, as Emeric himself died even before Stephan's death in 1031. It is important to mention that his death was much too profane for a saint ${ }^{28}$ and earlier authors have pointed to this discrepancy between the ascetic and secular Emeric, placing the picture of Emeric into broader analogies of ascetic persons from sovereign houses in Europe (Saint Olaf, Saint Edmund, Saint Wenceslaus, Saint Boris and Gleb). ${ }^{29}$ It is the Czech analogy with Saint Wenceslaus that is interesting, because the figure of Saint Wenceslaus is in fact - similar to Saint Emeric known solely from legends. Here, Wenceslaus is depicted as a saint who had been forced to perform the obligations of a monarch. Thus, we can read an absurd hyperbolae created by the author of the Legend, according to whom he was "ar-

\footnotetext{
${ }^{27}$ Still we can observe in her legend an obvious emphasis on the immateriality of love between her and her husband, the Duke of Bavaria (Vita S. Elisabethae 53-55).

${ }^{28}$ Emeric died in a hunting accident. Annales Hildesheimenses ad a. 1031, in: WAITZ, Scriptores rerum Germanicarum 36: "Et Heinricus, Stephani regis filius, dux Ruizorum, in venatione ab apro discissus, periit flebiliter mortuus."

${ }^{29}$ See MiKLós, Monachizmus.
}

dently longing for an unmarried life", and shortly before his death he tried to reach Rome in order to become a monk. ${ }^{30}$ This would actually have implied that he had never been married. Another legend on Wenceslaus, the Legend of Christian, indicates the opposite; that Wenceslaus was in fact married but kept "chastity". ${ }^{31}$ Contrary to the author of "Crescende fide", the author of Christian's legend was writing under the pressure of domestic tradition, and this did not allow him to describe Wenceslaus' family life in such a contradiction to reality. ${ }^{32}$

We can consider and interpret the text based on an analogy on Saint Wenceslaus and the interpretations arising from contradictions between the normativity of the Legend text and the historical facts in the Legend of St. Emeric. As in the case of Saint Wenceslaus, also here a certain time passed between the death and the writing of the legend. In the case of Emeric it is about half a century. It reduces the authenticity of the source, while not reducing the normative authority of the Legend.

The Legend of St. Emeric describes two remarkable facts linked to sexual morals. The first is depicted in the second chapter of the Legend, which contains the story of a common visit of King Stephan and his son Emeric to a Benedictian monastery of Saint Martin in Pannonhalma, during which the father and son were warmly welcomed by the local monks, and, according to tradition, the line of monks greeted them with kisses. Young Emeric did not kiss the monks evenly; one of them was kissed seven times, while another one only once. When later Stephan asked about that, he received the response

\footnotetext{
${ }^{30}$ Crescente fide, in: EMLER, Fontes rerum Bohemicarum I, 185.

${ }^{31}$ Legenda Christiani, c. 6., LuDvíKOvSKÝ, Vita et passio sancti Wenceslai 64: "Procerus vultu, castitatem aplectens, quamvis hec rara uxoratis ..."

32 For an analysis of Wenceslaus' personality based on legends and for other literature, see TřEšTík, Počátky Přemyslovců 375-388.
} 
from his young son Emeric that the monk who received seven kisses had led a virginal life. ${ }^{33}$

Two strange elements are mentioned in the text. The first is the boyish age of Emeric, who obviously, according to the legendist, was aware of the meaning of virginity. The other, and much more interesting phenomenon, is the unintentional revelation of the situation among the monks in the monastery, where celibacy should have been the rule. The author's note indicates that celibacy could have been rather an exception, not the rule.

In chapter four of the Legend, Emeric found himself in the Church of Saint George in Veszprém. Emeric - now an adult - says his prayers in the church and while he was contemplating how he could prove his devotedness to God, suddenly the voice of the Supreme Lord

${ }^{33}$ Legenda s. Emerici ducis 2, in: SZENTPÉTERY, Scriptores rerum Hungaricarum II, 452: “Quodam tempore, cum beatus rex Stephanus ad ecclesiam beati Martini, quam ipse in Sancto Monte Pannonie inchoaverat et egregia monachorum congregatione decoraverat, una cum filio causa orationis advenit, sed rex sciens pueri precellens meritum, onorem, quem (sic) eum decuit, inpendit filio. Nam cum predicti fratres peracta processione salutaturi regem accessissent, propter reverentiam filium suum premisit ad salutandum. Puer autem Henricus spiritu sancto repletus, prout divina revelante sibi gratia singulorum merita noverat, singulis inequaliter oscula distribuit. Alii siquidem unum, alii tria, alii vero quinque, postremo uni VII oscula continuavit. Quam rem, ceteris intuentibus, beatus rex Stephanus tacite admirabatur, familiarique colloquio, finita missa, cur illis inequaliter oscula distribuisset, diligenter $a b$ eo sciscitatus est. Beatus itaque Henricus singulorum merita coram patre pertractans, videlicet quanto temporis spatio singuli in virtute continentie perstitissent sub ea consideratione se plura aliis et pauciora aliis oscula dedisse edocuit, eumque cui septena multiplicaverat oscula virginalem vitam perduxisse asseruit. $\mathrm{O}$ excitatrix omnium virtutum gratia, que nostre angustias nature habundanter excedis, que profunda misteria revelas parvulis, tu beato Henrico magistra affuisti, tu ei liberam de ocultis aliorum intelligentiam contulisti. Huius autem interne revelationis veritas hoc modo est comperta in eo." was reportedly heard, saying: "Most glorious is virginity, I demand virginity of soul and body from You. Make this sacrifice and maintain it." 34

Paradoxically, Emeric was married and although his wife's identity is rather vague, reportedly, she was a virgin from a noble ruler's house; in relation to her he preferred, as the Legend says, virginal life to royal posterity. We may doubt the wording of the Legend (was not providing posterity one of the most important roles of the successor to the throne?), but the legend picturesquely describes the "admirableness of juvenile chastity", which demanded giving up human nature, so that they both were able to "despise the pleasure of married spouses" or "reject the loveliness of children". The future holiness should be substantial. ${ }^{35}$

In view of the values expressed, the text of this Legend may serve as a proof that marital and family life did not belong to traditional Christian values in the past. This example can show, contrary to the perhaps prevailing contemporary opinion, the dynamics of Christian values in historical development. Its substance was not to adore family and marital cohabitation, but the opposite: the life outside of marriage. The explanation was quite simple, namely a general disgust with the shedding of body liquids (blood and sperm) leading to an express ban on doing so, especially among clerics (oratores), where abstaining from physical fights and

\footnotetext{
${ }^{34}$ Legenda s. Emerici ducis 4, in: ibidem 453f.: “Contigit autem, ut dum nocte quadam orationis causa secreto, uno totum (sic) contentus famulo, vetustissimam et antiquissimam, que in Besprimiensi civitate ad honorem pretiosissimi Christi Georgii fabricata est, intraret ecclesiam, ibique orationi vacando, quid acceptabilius offerret deo, penes se retractaret, subito lumen cum ingenti claritate totum ecclesie circumfulsit edificium, in quo vox divina in supernis sic insonuit: „Preclara est virginitas, virginitatem mentis et corporis a te exigo. Hanc offer, in hoc persta proposito".

${ }^{35}$ Ibidem 454-456.
} 
avoiding sexual desires were expected. Life in marriage alone was not deemed worth following, however, it was acceptable at least, if performed within an indivisible Christian marriage. Thus, the hierarchy of the allowed sexual conduct had been formed: complete chastity in the first place within virginal life, widows' chastity in the second place and chastity within marriage in the third place only. ${ }^{36}$ Marriage became a not too preferred tool to manage oneself, where theology created an "ordo conjugatorum" and where a possibility to regulate sexual life existed, too. Also, here it was necessary to avoid an excessive sexual urge, because as Saint Augustine had already noted, even the one "who loves his wife too passionately, is a sinner". Church Fathers did not warn in vain that even the conception of children does not happen without $\sin .{ }^{37}$

Therefore, this part of traditional European Christianity can be felt from the Legend of Saint Emeric, before it was supressed by the urban societies of the late Middle Ages, where sexuality ceased to be perceived as a necessary wrong that should be rather avoided; instead societies begun to focus on suppressing the forbidden forms of sexuality.

Before the aforementioned approach prevailed in Europe, another remarkable source was preserved in Hungary, i.e. the Legend of Saint Margaret, daughter of the Hungarian King Bela IV (1035-1070). This legend is full of inaccuracies ${ }^{38}$

\footnotetext{
${ }^{36}$ It is quite interesting that the Legend of Saint Emeric, which is in favour of chastity and sexual abstinence, significantly emphasised the birth of Jesus from a womb that was virginal, i.e. of chaste character and uncharged with original sin. Legenda s. Emerici ducis 5, in: ibidem 455.

${ }^{37}$ LE GOFF, TRUONG. Tělo ve středověké kultuře 34-37; Rossiaud, Sexualita.

${ }^{38}$ For example, her putative prophecy on a result of the battle between King Bela IV and the Austrian Duke Frederick II Babenberg. See PRAŽÁK, Legendy a kroniky 156.
}

that may bring us to reasonable doubts regarding the reliability of individual aspects of this source, where the creator of the so-called basic legend was Margaret's confessor Marcellus. He recorded her life since her birth through her life in a monastery, until her death, which occurred at around the same time as that of her father.

Margaret, similarly to Emeric, to whom the legend refers, ${ }^{39}$ devoted her life to the monastery and the chaste life of a confessor. Unlike Emeric, she was not intended to live a secular life, therefore this does not sound so improbable. However, Margaret was twice offered as a wife by her father; once a marriage to the Prince of Poland was considered and once to the King of Bohemia Přemysl Otakar II. According to the legend, she declined both options. ${ }^{40}$

Margaret's chastity was hyperbolized in the legend by her affection for dirty attire and an unattractive appearance and poverty. In addition, she strongly disliked to get washed more than above her knees, so she was reported not to have taken a bath for seventeen years, not even after she had recovered from her frequent health conditions. ${ }^{41}$

${ }^{39}$ Vita beatae Margitae de Hungaria, c. 12, in: Csepregi, Klaniczay, Péterfi, Legenda vetus 58, 60: "Revolvebat crebrius secum et conferebat cum aliis interdum progenitorum suorum vitam et vite sanctitatem: Beati scilicet Stephani, primi regis et apostoli Ungarorum, cuius fidem et catholice fidei predicationem, qua suam convertit gentem ab ydulorum cultura, ecclesia narrat vulgarica; Beati Henrici, filii eiusdem Sancti Stephani regis sanctissimam virginitatem, qui cum haberet sponsam nobilissimam, utpote filiam imperatoris Romanorum divinitus facta sibi revelatione, ut in eius gestis habetur, virginalem cunctis diebus vite sue cum sua sponsa illibatam servavit castitatem, quod maxime testimonio eiusdem sponse sue fuit post obitum suum efficaciter comprobatum." From this text we can see that the author directly knew and used the Legend of Saint Emeric, as he quoted its fifth chapter, depicting the testimony of Emetic's wife on their common life.

${ }^{40}$ Ibidem, c. 16, 64, 66.

${ }^{41}$ Ibidem, c. 10, 55 . 
Both legendary texts from the $11^{\text {th }}$ and $13^{\text {th }}$ centuries prove the influence of the ideal of chastity and sexual rigorousness, which could be seen as suggested in the Life of Constantine. Moral rules could have been contrasted with legal texts in the case of the Moravian legends, which, however, can be rather difficult for the Arpád House period. For example, the entire Regestrum Varadiense comprises dominating violent and property crimes, while the list of sexual wrongs is limited to mere adultery (adulteria). ${ }^{42}$ The Arpádian codes are also rather limited in this respect, as sexual wrong can only be found in the ban on kidnapping girls. ${ }^{43}$ Otherwise, these codes contain predominantly the rules that could be part of contemporary family law, not criminal law. It is in particular the principle of the indivisibility of marriage in Coloman's laws, stipulating the impossibility of a wife abandoning her husband, but not vice versa. Therefore, marriage could be terminated after certain prerequisites had been met: infidelity on the part of the wife, repeated sanction of slavery; as for the wife, a second marriage was possible in the case of a husband's wrongful abandonment. ${ }^{44}$

Thus, it is reasonable to supplement these wrongs with equally interesting information from the Hungarian chronicles. Initially, we should mention the part of the Hungarian chronical composed in the $14^{\text {th }}$ century which is the basis for the history of Hungary in the $11^{\text {th }}$ and $12^{\text {th }}$ centuries..$^{45}$ The part relating to the rule

${ }^{42}$ KARÁCSONYI, BOROVSZKY, Regestrum Varadiense 268.

${ }^{43}$ Zákony krála Štefana I., 25, in: SEGEŠ, ŠEĎOVÁ, Pramene k vojenským dejinám Slovenska 21.

${ }^{44}$ See analysis in: LUBY, Dejiny súkromného práva $319 f$.

${ }^{45}$ Let us not forget that this source one way or another originated from the unpreserved work Gesta Hungarorum Vetera from the period of the reign of King Louis I. See PRAŽÁK, Legendy a kroniky 13 and Žitije Konstantina, in: BARTOŇKOVÁ, Magnae Moraviae fontes historici II, 31. Here is also another piece of literature. According to MARSINA, Stredoveké uhorské of Peter Orseolo (1038-1041, 1044-1046) describes very colourfully and with extraordinary bias the reasons for the discontent of the Hungarians with Peter, who had established a tyranny where nobody could have relied on the innocence of his wife, daughter and sister as they were reportedly abused by the King's men. ${ }^{46}$

It could be questionable whether in this case the indignation over the cruelties of Peter Orseolo and his men resulted from the prude or from natural attitudes to violence committed towards women, typical of every society. After all, the author's goal was an effort to draw (and no doubt to exaggerate) humiliation on Peter's men, moreover the strangers. The text contains nationally stressed stereotypes of "Germans, roaring like wild animals" and on "Italians, twittering away like swallows", who were said to have committed sexual assaults, and Peter was supposed to pass over the country to the Germans. ${ }^{47}$ When reading these statements, it must be remembered that it was not only a stereotypical attitude towards strangers (what worse can strangers do than to rape "our" women?), but apparent is also the literary topos known in the Central European environment from very similar stories on the rise of the Kingdom of Samo. They were recorded in two sources independent

rozprávacie pramene 171, the author of Gesta should have used for his purposes some older source from the mid-11 $11^{\text {th }}$ century, too.

${ }^{46}$ Chronici Hungarici compositio saec. XIV, c. 71, in: SZENTPÉTERY, Scriptores rerum Hungaricarum I, 323: “[...] nullusque eo tempore tutus esse poterat de pudicitia uxoris sue vel filie seu sororis virginitate insultus satellitum regis, qui eas impune violabant." It is remarkable that the author of the Hungarian Gesta overwrote information on Peter Orseolo's government using a source from the Roman-German Empire, where such an abuse is in Orseolo's case not depicted. Therefore, it is necessary not to trust the Hungarian source.

${ }^{47}$ Ibidem. 
from one another, the so-called Fredegar's chronicle and the Russian Tale of Bygone Years.

Both sources attempted to describe reasons for the rebellion of the Slavs against the Avars that were seen in the Avarian supremacy. According to the Tale of Bygone Years from the beginning of the $12^{\text {th }}$ century, it was manifested by the harassment of Slavic Dudlebes by the Avars (Объре) and the violence towards Dudlebian women who were to serve as beasts of draught to Avars. ${ }^{48}$ Other types of violence towards Slavic women are mentioned in the source of the time, Fredegar's chronicle. According to its author, Avars (Chuni) used to come to the Slavs to spend winter there, taking their wives and daughters. Descents of Avars and Slavs rebelled then against the Avars, creating the Kingdom of Samo. $^{49}$

There is no use in analysing the veraciousness or truthlessness of the tales of enslaved Slavs and Dudlebian sexual slaves or the winter habits of the Avars. We can only assume that such tales could reflect reality at least partially. They need not be rejected only because they look like stereotypes. They seem to be much more credible than the Hungarian source marked by the author's national bias, while apparently manipulating with his information. Therefore, we shall find dubious the demands of the author of the Hungarian Gesta of the $11^{\text {th }}$ century (the original text for the Compilation of Chronicles of the $14^{\text {th }}$ century) not only in respect of its historical authenticity, but also in view of Christian morals.

Much closer to our topic is the story of the second wife of the Hungarian King Coloman, who came to Hungary from the Kievan Rus. According to the Hungarian Chronicle, the King caught

\footnotetext{
${ }^{48}$ Latopis Nestora, c. 8, in: BIELOWSKI, Monumenta Poloniae historica 557. For an analysis of the problem, see ZÁsTĚrovÁ, Avaři a Dudlebové 15-37.

${ }^{49}$ Chronicarum quae dicuntur Fredegarii scholastici libri IV cum Continuantibus, IV, 48, in: KURSCH, Scriptores rerum Merovingicarum 144f.
}

her when she was committing adultery and dismissed her from the marriage. The author of the Chronicle stresses that the King applied no violence when doing so, and emphasises that this did not occur contrary to law (sine lege); no divorce occurred, but separation only due to her sin (non ipse ab ea se separavit). The law (lex) thus sent her back to her homeland, where she gave birth to her son Boris out of wedlock. ${ }^{50}$

Ostensive emphasis on compliance with the law seems to reflect the background of King Coloman. The Hungarian Chronicler obviously disliked him; he depicted him as weak, sly and docile, dishevelled, hairy, half-blind, hunchbacked, lame and mumbling. ${ }^{51}$ On the other hand, the Polish Chronicler Gallus Anonymus described him as a ruler who outclassed other kings in respect of education ${ }^{52}$ (no wonder that he was nicknamed 'the Bookish'); moreover, before he became king, he had been a bishop in Varadine, and obviously he was well aware of family law rules. Similarly, he knew the family law rules listed in the Arpadian codes, and some of them can be also found in the Coloman code.

When referring to these rules, it should be said that the developing canon law had to compromise the issue of the indivisibility of marriage, considering the possibilities of a newly Christianised society. ${ }^{53}$ The church not always acted in line with the monarch, as monarchs themselves had their own interests to enforce. As an example, some monarchs directly refused to enter into marriage (the Hungarian King Stephan II, 1116-1131, who rejected to get married, preferring the life with mistresses and prostitutes). It was eventually the Hungarian nobility which decided to bring the daughter of King of

\footnotetext{
50 Ibidem, c. $149,429$.

${ }^{51}$ Ibidem, c. 143, 421.

${ }^{52}$ Galli chronicon II, 29, in: BIELOWSKI, Monumenta Poloniae historica 448.

${ }^{53}$ LuBY, Dejiny súkromného práva 319.
} 
Apulia Robert Guiscard to become Stephan's wife. ${ }^{54}$

As we can see, the material in non-legal sources of the Hungarian Middle Ages is quite abundant. Not taking into account the question whether it is possible to verify the content, they should be deemed reliable sources in respect of their normative binding force and point to hypothesis on the parallel effect of the rules of both archaic law and canon law in the early and high Middle Ages.

\section{Korrespondenz:}

Doz. Dr. Miroslav LysÝ

Comenius University, Faculty of Law

Department of Legal History and Comparative Law

Šafárikovo námestie č. 6, P.O.BOX 313

81000 Bratislava, Slovakia

miroslav.lysy@flaw.uniba.sk

ORCID-Nr. 0000-0002-4242-240X

\section{Abkürzungen:}

Siehe das allgemeine Abkürzungsverzeichnis: [http://www.rechtsgeschichte.at/files/abk.pdf]

${ }^{54}$ Chronici Hungarici compositio saec. XIV, c. 154, in: SZENTPÉTERY, Scriptores rerum Hungaricarum I, 437: "Rex autem Stephanus legittimam nolebat ducere uxorem, sed concubinis meretricibus iunctus erat. Quare barones et optimates dolentes de regni desolatione et regis sterilitate duxerunt ei uxorem dominam nobilissimam, filiam regis Robert Viscardi de Apulia." 


\section{Literatur:}

Dagmar BARTOŇKOVÁ et al. (eds.), Magnae Moraviae fontes historici, vol. II: Textus biographici, hagiographici, liturgici (Brno 1967).

ID. et al. (eds.), Magnae Moraviae fontes historici, vol. III: Diplomata, epistolae, textus historici varii (Brno 1969).

August BIELOWSKI (ed.), Monumenta Poloniae historica, vol. I (Lwów 1864).

Ildikó Csepregi, Gábor Klaniczay, Bence PÉTERfi (eds.). Legenda vetus, Acta processus canonizationis et Miracula Sanctae Margitae de Hungaria (Budapest-New York 2018)

Zdeněk R. DITTRICH, Christianity in Great-Moravia (Groningen 1962).

Josef EMLER (ed.), Fontes rerum Bohemicarum, vol. I. (Pragae 1873).

Vasil GLUCHMAN, Krestanstvo a morálka v stredoeurópskej politike 9. storočia, in: Konštantínove listy, 10/2 (2017) 62-74.

Hans HattenHauer, Evropské dějiny práva (Praha 1998).

Lubomír HAVLÍK et al. (eds.), Magnae Moraviae fontes historici, vol. IV: Leges, Textus iuridici, Supplementa, (Brno 1971).

Róbert JÁGER, Nomokánon. Právnohistorická analýza a transcript (Banská Bystrica 2017).

Joannes KARÁCSONYI, Samuel BOROVSZKY (eds.), Regestrum Varadiense examinum ferri candentis ordine chronologico digestum (Budapest 1903).

Karel KizLINK, Právo Velkej Moravy, in: Právnické štúdie 17 (1969) 433-490.

Matúš KUČERA, Král Svätopluk (830? - 846 - 894) (Martin 2010).

Bruno KURSCH (ed.), Scriptores rerum Merovingicarum, vol. II: Fredegarii et aliorum Chronica. Vita sanctorum (Hannoverae 1888).

Jacques LE GOFF, Nicolas TRUONG, Tělo ve středověké kultuře (Praha 2003).

Štefan LUBY, Dejiny súkromného práva na Slovensku (Bratislava 22002).

Jaroslav LUDVÍKOVSKÝ (ed.), Vita et passio sancti Wenceslai et sancte Ludmile ave eius (Prague 2012).

Richard MARSINA, Stredoveké uhorské rozprávacie pramene a slovenské dejiny, in: Zborník Slovenského národného múzea 78 (1984) 171.
ID., Obnovenie Nitrianskeho biskupstva, in: Nitra v najstarších dokumentoch a písomnostiach (do konca 13. storočia). Zborník príspevkov z konferencie, ktorá sa konala $\mathrm{v}$ aule Teologického inštitútu Sv. Gorazda v Nitre dňa 14. decembra 2006 (Nitra 2007) 35-45.

Péter MiKLós, A monachizmus és a tisztaság erénye Szent Imre herceg legendájában, in: Aetas 17/3 (2002) 89-96.

Georgius Heinricus PERTZ (ed.), Monumenta Germaniae historica, Scriptorum IV (Hannoverae 1841).

Richard PRAŽÁK (ed.). Legendy a kroniky koruny uherské (Praha 1988).

Jacques RossiaUd, Sexualita, in: Jacques Le GofF, JeanClaude SchmitT (eds.), Encyklopedie středověku (Praha 2002) 641-648.

Vladimír SEgEš, Božena ŠEĎOVÁ (eds.), Pramene k vojenským dejinám Slovenska, vol. I/2: 1000 1387 (Bratislava 2011).

Ján STANISLAV, Starosloviensky jazyk, vol. I. (Bratislava 1978).

Emericus SZENTPÉTERY (ed.), Scriptores rerum Hun garicarum tempore ducum regumque stirpis Arpadianae gestarum, vols. I-II (Budapestini 1937-1938).

Dušan TřešTík, Počátky Přemyslovců. Vstup Čechů do dějiny 530-935 (Praha 1997).

ID., Zápisník a jiné texty $\mathrm{k}$ dějinám (Praha 2008).

ID., Co se stalo 28. záŕí 995 na Libici?, in: Jiří K. KROUPA et al. (eds.), Po stopách svatého Vojtěcha (Praha 2014) 63-71.

Josef VAŠICA, Literární památky epochy velkomoravské (Praha 1966).

Vita S. Elisabethae viduae landgraviae Thuringiae, ducis Saxoniae, Hassiae principis et comitis palatinae, nec non B. Margarithae virginis quarum illa Andreae II. haec Belae IV. Hungariae regum filia erat. Ex mss. codicibus eruta, ac praeviis dissertationibus illustrata (Tyrnaviae 1770).

Georg WAITZ (ed.), Scriptores rerum Germanicarum in usum scholarum ex Monumentis Germaniae historicis recuse (Hannoverae 1878).

ID. (ed.), Monumenta Germaniae historica, Scriptorum, vol. 25 (Hannoverae 1880).

Bohumila ZÁsTĚrovÁ, Avaři a Dudlebové v svědectví Povesti vremennych let, in: Vznik a počátky Slovanů, vol. III (Praha 1960) 15-37. 